University of Michigan Law School University of Michigan Law School Scholarship Repository

2007

\title{
Tax Competition, Tax Arbitrage and the International Tax Regime
}

Reuven S. Avi-Yonah

University of Michigan Law School, aviyonah@umich.edu

Available at: https://repository.law.umich.edu/articles/1161

Follow this and additional works at: https://repository.law.umich.edu/articles

Part of the International Law Commons, Taxation-Transnational Commons, and the Tax Law Commons

\section{Recommended Citation}

Avi-Yonah, Reuven S. "Tax Competition, Tax Arbitrage and the International Tax Regime." Bull. for Int'1 Tax'n 61, no. 4 (2007): 130-8.

This Article is brought to you for free and open access by the Faculty Scholarship at University of Michigan Law School Scholarship Repository. It has been accepted for inclusion in Articles by an authorized administrator of University of Michigan Law School Scholarship Repository. For more information, please contact mlaw.repository@umich.edu. 


\section{Tax Competition, Tax Arbitrage and the International Tax Regime}

\section{Contents}

1. Introduction

2. Is There an International Tax Regime?

3. Is the International Tax Regime Part of International Law?

3.1. Jurisdiction to tax

3.2. Non-discrimination

3.3. The arm's length standard

3.4. Foreign tax credits versus deductions

3.5. Concluding remarks

4. The Structure of the International Tax Regime

4.1. Defining the tax base: the single tax principle

4.2. Dividing the tax base: the benefits principle

5. Current Challenges to the International Tax Regime

5.1. Tax competition for passive investment

5.2. Tax competition for active investment

5.3. Tax arbitrage

6. Conclusion

\section{Introduction}

In the past ten years, I have argued repeatedly that a coherent international tax regime exists, embodied both in the tax treaty network and in domestic laws, and that it forms a significant part of international law (both treaty-based and customary). The practical implication is that countries are not free to adopt any international tax rules they please, but rather operate in the context of the regime, which changes in the same ways international law changes over time. Thus, unilateral action is possible, but is also restricted, and countries are generally reluctant to take unilateral actions that violate the basic norms that underlie the regime. Those norms are the single tax principle (i.e. that income should be taxed once - not more and not less) and the benefits principle (i.e. that active business income should be taxed primarily at source and passive investment income primarily at residence).

This thesis is quite controversial. Several prominent international tax academics and practitioners in the United States (e.g. Michael Graetz, David Rosenbloom, Julie Roin and Mitchell Kane) and elsewhere (e.g. Tsilly Dagan) have advocated the view that there is no international tax regime and that countries are free to adopt any tax rules they believe further their own interests. ${ }^{1}$ Other prominent tax academics (e.g. Hugh Ault, Yariv Brauner, Paul McDaniel, Diane Ring and Richard Vann) and practitioners (e.g. Luca dell'Anese, Shay Menuchin and Philip West) have supported the view advocated above. ${ }^{2}$ There is, however, no coherent exposition of this view in the academic or practical literature. This article is intended to fill this gap, following up on previous articles in which I developed the above thesis. ${ }^{3}$
The article is divided into four parts. The first part argues that an international tax regime exists, embodied both in the tax treaty network and in the domestic tax laws of the major trading nations. Illustrations are provided from recent developments that show countries like the United States and Germany complying with the basic norms of the regime, such as non-discrimination. The second part argues that the international tax regime is an important part of international law as it evolved in the 20th century. In particular, the article argues that parts of international tax law can be seen as customary international law and therefore as binding even in the absence of treaties. An example is the arms length standard under transfer pricing. The third part of the article explains the basic structure of the international tax regime and its underlying norms, the single tax principle and the benefits principle. The third part also sets out the normative rationale for these norms. The fourth part discusses recent challenges to the international tax regime, such as tax competition and tax arbitrage, and argues that the reaction to these challenges by the OECD, the WTO, the European Union and specific tax administrations proves the existence of the international tax regime.

\footnotetext{
* Irwin I. Cohn Professor of Law and Director, International Tax LLM,
} the University of Michigan.

1. Graetz, Michael J., "Taxing International Income: Inadequate Principles, Outdated Concepts, and Unsatisfactory Policies”, 26 Brooklyn Journal of International Law 1357 (2001); Rosenbloom, H. David, "Cross-Border Arbitrage: The Good, The Bad and The Ugly" (forthcoming in Taxes (University of Chicago publication), 2006); Rosenbloom, H. David, "International Tax Arbitrage and the 'International Tax System"', 53 Tax Law Review 137 (2000); Roin, Julie, "Competition and Evasion: Another Perspective on International Tax Competition”, 89 Georgetown Law Journal 543 (2001); Dagan, Tsilly, “The Tax Treaties Myth", 32 NYU Journal of International Law and Policy 939 (2000); Kane, Mitchell A., "Strategy and Cooperation in National Responses to International Tax Arbitrage", 53 Emory Law Journal 89 (2005).

2. Dell'Anese, Luca, Tax Arbitrage and the Changing Structure of International Tax Law (2006); Ring, Diane M., "One Nation Among Many: Policy Implications of Cross-Border Tax Arbitrage", 44 Boston College Law Review 79 (2005); Menuchin, Shay N., The Dilemma of International Tax Arbitrage (2004); Ault, Hugh J., "The Importance of International Cooperation in Forging Tax Policy”, 26 Brooklyn Journal of International Law 1693 (2001); McDaniel, Paul R., "Trade and Taxation", 26 Brooklyn Journal of International Law 1621 (2001); Vann, Richard J., "International Aspects of Income Tax", in Thuronyi, Victor (ed.), 2 Tax Law Design and Drafting 718 (2000); West, Philip R., "Foreign Law in U.S. International Taxation", 3 Florida Tax Review 147 (1996).

3. See e.g. Avi-Yonah, Reuven S., "The Structure of International Taxation: A Proposal for Simplification”, 74 Texas Law Review 1301 (1996); Avi-Yonah, Reuven S., "International Taxation of Electronic Commerce", 52 Tax Law Review 507 (1997); and Avi-Yonah, Reuven S., "Globalization, Tax Competition, and the Fiscal Crisis of the Welfare State", 113 Harvard Law Review 1573 (2000). 


\section{Is There an International Tax Regime? ${ }^{4}$}

The most important statement denying the existence of the international tax regime is the 1998 Tillinghast Lecture delivered by H. David Rosenbloom at New York University Law School. ${ }^{5}$ He began his lecture by quoting from the legislative history of the US dual consolidated loss rule a statement referring to an "international tax system". He then proceeded to deny the existence of this system or regime ("that system appears to be imaginary") because, in the real world, only the different tax laws of various countries exist, and those laws vary greatly from each other.

Of course, this description is true as far as it goes, but is this the whole truth? As Rosenbloom noted, in fact, there has been a remarkable degree of convergence even in the purely domestic tax laws of developed countries. Not only can tax lawyers talk to each other across national boundaries and understand what each is saying (the terminology is the same), but the need to face similar problems in taxing income has also led jurisdictions with different starting points to reach quite similar results. For example, countries that started off with a global tax system (i.e. tax all income from whatever source derived in the same way) have now incorporated schedular elements (for example, the capital loss and passive activity loss rules in the United States), whereas countries with a schedular background (i.e. tax different types of income differently) have largely adopted schedules for "other income" that lead to a global tax base (for example, the United Kingdom).

Not surprisingly, this convergence is most advanced in international tax matters because, in this case, the tax laws of various jurisdictions actually interact with each other and one can document cases of direct influence. For example, every developed country now tends to tax currently passive income derived by its residents overseas (through controlled foreign corporation (CFC) and foreign investment funds (FIF) rules, which were inspired by the US example) and to exempt or defer active business income. Thus, the distinction between countries that assert worldwide taxing jurisdiction and those that only tax territorially has lost much of its force. Other examples of such convergence are developed in the course of this article.

The claim that an international tax regime exists, however, rests mainly on the bilateral tax treaty network, which, as Rosenbloom stated, is "a triumph of international law". The treaties are, of course, remarkably similar (even as to the order of the articles), being based on the same OECD and UN Model Tax Conventions. In most countries, the treaties have a higher status than domestic law and thus constrain domestic tax jurisdiction; and even in the United States, the treaties typically override contrary domestic law. This means that, in international tax matters, countries typically are bound by treaty to behave in certain ways (for example, not tax a foreign seller who has no permanent establishment) and cannot enact legislation to the contrary.
I would argue that the network of 2,000 or more bilateral tax treaties that are largely similar in policy, and even in language, constitutes an international tax regime which has definable principles that underlie it and are common to the treaties. These principles are the single tax principle and the benefits principle, which are articulated further below. In brief, the single tax principle states that income from cross-border transactions should be subject to tax once (that is, not more, but also not less, than once) at the rate determined by the benefits principle. The benefits principle allocates the right to tax active business income primarily to the source jurisdiction and the right to tax passive investment income primarily to the residence jurisdiction.

To those who doubt the existence of the international tax regime, let me pose the following question. If you were advising a developing country or transition economy that wanted to adopt an income tax for the first time, how free do you think you would be to write the international tax rules for such a country in any way you wanted, assuming that it wished to attract foreign investment? I would argue that the freedom of most countries to adopt international tax rules is severely constrained, even before entering into any tax treaties, by the need to adapt to generally accepted principles of international taxation. Even if divergent rules have been adopted, the process of integration into the world economy forces change. For example, Mexico had to abandon its long tradition of applying formulas in transfer pricing and adopt rules modelled after the OECD guidelines in order to be able to join the OECD. South Korea similarly had to change its broad interpretation of what constitutes a permanent establishment under pressure from the OECD. And Bolivia had to abandon its attempt to adopt a cash-flow corporate tax because the tax was ruled not creditable in the United States. Even the United States is not immune to this type of pressure to conform, as can be seen from comparing the 1993 proposed transfer pricing regulations under US Internal Revenue Code (IRC) Sec. 482, which led to an international uproar, with the final regulations, which reflect the OECD guidelines.

Another illustration can be derived from recent developments in both the US and Germany regarding the application of the non-discrimination principle, which is embodied in all tax treaties, to thin capitalization rules that are designed to prevent foreign taxpayers from eliminating the corporate tax base through capitalizing domestic subsidiary corporations principally with debt. When the US first adopted its thin capitalization rule in 1989 , the US carefully applied it to both foreigners and domestic tax exempts so as not to appear to be denying interest deductions only to foreigners. The US did this even though thin capitalization rules are an accepted

4. This part is based on Avi-Yonah, "Globalization, Tax Competition, and the Fiscal Crisis of the Welfare State", supra note 3.

5. Rosenbloom, "International Tax Arbitrage and the 'International Tax System", supra note 1 . 
part of international tax law and even though its constitutional law permits unilateral overrides of tax treaties. The Germans adopted the same rule, but when it was nevertheless struck down as discriminatory by the European Court of Justice in 2002, they responded by applying the thin capitalization rule to all domestic as well as foreign taxpayers. Neither the US nor the German actions are understandable in the absence of an international tax regime embodying the non-discrimination principle.

\section{Is the International Tax Regime Part of International Law? ${ }^{6}$}

Few would dispute that the network of bilateral tax treaties forms an important part of international law. Thus, the key issue is whether these treaties and the domestic tax laws of various jurisdictions can be said to form an international tax regime that is part of customary international law.

Customary international law is law that "results from a general and consistent practice of states followed by them from a sense of legal obligation"? "International agreements create law for states parties thereto and may lead to the creation of customary international law when such agreements are intended for adherence by states generally and are in fact widely accepted."

There are clearly international tax practices that are widely followed, such as, for example, avoiding double taxation by granting an exemption for foreign-source income or a credit for foreign taxes. Moreover, there are over 2,000 bilateral tax treaties in existence, and they all follow one of two widely accepted models (the OECD and UN Models), which themselves are quite similar to each other and are "intended for adherence by states generally". Is this enough to create a customary international tax law?

The discussion below briefly surveys some examples that, in my opinion, strengthen the view that the international tax regime rises to the level of customary international law. As usual, the hard question is whether countries not only follow a rule, but do so out of a sense of legal obligation (opinio juris).

\subsection{Jurisdiction to tax}

Can a country simply decide to tax non-residents that have no connection to it on foreign-source income? The answer is clearly no, both from a practical perspective and, I would argue, from a customary international law perspective. The fact that this rule is followed from a sense of legal obligation is illustrated by the behaviour of the US in adopting the FPHC (foreign personal holding company) and CFC rules. In the case of corporations controlled by US residents, the US does not tax those corporations directly, but rather taxes the US resident shareholders on imaginary (deemed) dividends distributed to the shareholders. This deemed dividend rule was adopted precisely because the US felt bound by a customary international law rule not to tax non-residents directly on foreign-source income, even though they are controlled by residents. The US no longer feels bound by this rule, but that is because enough other countries have adopted CFC legislation which expands the definition of nationality that customary international law has changed. The spread of CFC legislation from 1962 onward is a good example of how rapidly customary international law can in fact change.

\subsection{Non-discrimination}

The non-discrimination norm (i.e. that non-residents from a treaty country should not be treated worse than residents) is embodied in all tax treaties. But is it part of customary international law? The behaviour of the US in the earnings-stripping (thin capitalization) episode described above suggests that the US felt at the time that the non-discrimination norm was binding even outside the treaty context. Otherwise, even if the US did not wish to override treaties, it could have applied a different rule to non-treaty country residents (as it did in the branch profits tax context three years earlier). Thus, I would argue that the non-discrimination norm may in fact be part of customary international law even in the absence of a treaty.

\subsection{The arm's length standard}

The standard applied in all tax treaties to the transfer pricing problem of determining the proper allocation of profits between related entities is the "arm's length standard", which means that transactions between related parties may be adjusted by the tax authorities to the terms that would have been negotiated had the parties been unrelated to each other. This standard has been the governing rule since the 1930s.

In the 1980s, the US realized that in many circumstances it is very difficult to find comparable transactions between unrelated parties on which to base the arm's length determination. The US therefore began the process of revising the regulations that govern transfer pricing. This culminated in 1995 with the adoption of two new methods, the comparable profit method and profit split method, that rely much less on finding comparables (and, in the case of profit split, sometimes require no comparables at all).

What is remarkable about the process by which these regulations were adopted is the US's insistence throughout that what it was doing was consistent with the arm's length standard. The US even initially called profit split the "basic arm's length return method". But as I have pointed out elsewhere, once you abandon the search for comparables, it is meaningless to call a method "arm's

\footnotetext{
6. This part is based on Avi-Yonah, Reuven S., "International Tax as International Law", 57 Tax Law Review 483 (2004).

7. American Law Institute, Restatement of the Law Third: The Foreign Relations Law of the United States (1987), Sec. 102(2)

8. Id., Sec. 102(3)
} 
length" because, without comparables, nobody can know what unrelated parties would have done. ${ }^{9}$

Nevertheless, despite initial objections, the OECD ultimately came to accept the gist of the new methods in its revised transfer pricing guidelines, which were issued a short time after the new US regulations and represent the widely followed consensus view of transfer pricing. The new methods are thus accepted under the rubric of "arm's length".

As Brian Lepard has suggested, the US's insistence that it was following the arm's length standard indicates that it felt that the standard is part of customary international law. ${ }^{10}$ Such a finding has important implications because the US states explicitly follow a non-arm's length method, formulary apportionment, which has been twice upheld by the US Supreme Court. If the arm's length method is customary international law, the US Supreme Court cases may have been wrongly decided, as customary international law is part of federal law and arguably pre-empts contrary state law.

\subsection{Foreign tax credits versus deductions}

Many economists argue that countries should give only a deduction for foreign taxes rather than a credit. However, countries generally grant either an exemption for foreign-source income or a credit for foreign taxes paid. Remarkably, in most cases (following the lead of the US), this is done even in the absence of a treaty. It is likely that, at this point, countries consider themselves in practice bound by the credit or exemption norm, and a country would be highly reluctant to switch to a deduction method instead. Thus, arguably, preventing double taxation through a credit or exemption has become part of customary international law.

\subsection{Concluding remarks}

If customary international tax law exists, this has important implications for the US and other countries. As Justice Gray wrote over 100 years ago in the Paquete Habana case:

\begin{abstract}
International law is part of our law, and must be ascertained and administered by the courts of justice of appropriate jurisdiction as often as questions of right depending upon it are duly presented for their determination. For this purpose, where there is no treaty and no controlling executive or legislative act or judicial decision, resort must be had to the customs and usages of civilized nations. (175 U.S. 677 (1900), at 700)
\end{abstract}

To the extent legislation exists, it can in the US override customary international law as well as treaties. But in the absence of treaties or legislation, resort can be had to customary international law; and I would argue that it can also be used to ascertain the underlying purposes of treaties.

To the extent customary international tax law exists, this suggests that it is a mistake to deny the existence of an international tax system or regime. Admittedly, even if an international tax regime exists, we do not know what we should do about it - this has to be investigated in each particular case. But we should not pretend that there are no binding, widely accepted international tax norms that we should flout only when significant national interests are at stake. This view has important implications whenever differences between countries' domestic laws lead to the possibility of tax arbitrage, which is discussed further below.

\section{The Structure of the International Tax Regime $^{11}$}

If an international tax regime exists, what does it look like? The following sections define the two basic principles which, in my view, underlie the international tax regime and discuss why they are normatively justified.

\subsection{Defining the tax base: the single tax principle}

International income taxation involves two basic questions:

(1) What is the appropriate level of taxation for income from cross-border transactions?

(2) How are the resulting revenues to be divided among the taxing jurisdictions?

The answer to the first question is the single tax principle: income from cross-border transactions should be subject to tax once (that is, neither more nor less than once). The single tax principle thus incorporates the traditional goal of avoiding double taxation, which was the main motive for setting up the international tax regime in the 1920s and 1930s. Taxing cross-border income once also means, however, that it should not be undertaxed or (at the extreme) be subject to no tax at all.

The appropriate rate of tax for purposes of the single tax principle is determined by the second principle of international taxation, the benefits principle. The benefits principle, discussed below, assigns the primary right to tax active business income to source jurisdictions and the primary right to tax passive income to residence jurisdictions. Therefore, the rate of tax for purposes of the single tax principle is generally the source rate for active business income and the residence rate for passive (investment) income. When the primary jurisdiction refrains from taxation, however, residual taxation by other (residence or source) jurisdictions is possible and may be necessary to prevent undertaxation. Such residual taxation means that all income from cross-border transactions, under the single tax principle, should be taxed at least at the source rate (which tends to be lower than the residence rate), but at no more than the residence rate.

What is the normative basis for the single tax principle? As an initial matter, I assume that most countries would like to maintain both a personal income tax and a corporate income tax. The reasons for having both a personal

9. Avi-Yonah, Reuven S.,"The Rise and Fall of Arm's Length: A Study in the Evolution of U.S. International Taxation”, 15 Virginia Tax Review 89 (1995).

10. Lepard, Brian D., "Is the United States Obligated to Drive on the Right", 10 Duke Journal of Comparative \& International Law 43 (1999).

11. This part is based on Avi-Yonah, Reuven S., "International Taxation of Electronic Commerce", supra note 3 . 
income tax and a corporate income tax have been discussed extensively elsewhere and are not repeated here. ${ }^{12}$ For purposes of justifying the single tax principle, it is sufficient that most countries in fact maintain their existing personal and corporate income taxes.

Given a preference for imposing both a personal income tax and a corporate income tax on the domestically derived income of individuals and corporations, it becomes relatively easy to establish why the single tax principle is justified as a goal of the international tax regime, on both theoretical and practical grounds. From a theoretical perspective, if income derived from crossborder transactions is taxed more heavily than domestic income, the added tax burden creates an inefficient incentive to invest domestically. This proposition is widely accepted and underlies the effort, which by now is about a century old, to prevent or alleviate international multiple taxation.

The corollary also holds true: if income from cross-border transactions is taxed less heavily than domestic income, this creates an inefficient incentive to invest internationally rather than at home. The deadweight loss from undertaxation is the same as that from overtaxation.

In addition, there is a strong equity argument against the undertaxation of cross-border income, which applies to income earned by individuals. From an equity perspective, the undertaxation of cross-border income violates both horizontal and vertical equity when compared to higher tax rates imposed on domestic-source income, and in particular on domestic labour income. In this case, the argument that equity violations tend to turn into efficiency issues does not hold because labour is less mobile than capital and wage earners typically do not have the ability to transform their domestic wages into foreign-source income.

On a practical level, the single tax principle can be justified because double taxation leads to tax rates that can be extremely high and tend to stifle international investment. Zero taxation, on the other hand, offers an opportunity to avoid domestic taxation by investing abroad, and therefore threatens to erode the national tax base. T.S. Adams, the architect of the foreign tax credit and a major influence in shaping the international tax regime, recognized both of these propositions in the 1920s. In justifying the foreign tax credit, Adams wrote that "the state which with a fine regard for the rights of the taxpayer takes pains to relieve double taxation, may fairly take measures to ensure that the person or property pays at least one tax". Contrary to an exemption system, Adams's credit operated to eliminate double taxation by both source and residence jurisdictions, but preserved residual residence-based taxation to enforce the single tax principle. ${ }^{13}$

The practical justification for the single tax principle can be seen most easily if one imagines a world with only two countries, A and B, and only two companies, X (a resident of $\mathrm{A}$ ) and $\mathrm{Y}$ (a resident of $\mathrm{B}$ ). If both $\mathrm{A}$ and $\mathrm{B}$ tax the foreign-source income of their residents and the domestic-source income of foreigners, and neither gives relief from double taxation, then both $\mathrm{X}$ and $\mathrm{Y}$ would minimize their taxes by deriving only domestic-source income (since any foreign tax would by definition be an added burden). The result would be adequate revenues collected by both A and B, but no cross-border trade or investment.

On the other hand, suppose both A and B exempted from tax the foreign-source income as well as the domestic-source income of foreigners (a not inconceivable proposition in many developing countries, which tax residents territorially and grant tax holidays to foreign investors). In that case, the way for both $\mathrm{X}$ and $\mathrm{Y}$ to minimize their taxes would be to derive their entire income from cross-border transactions. The result would be adequate cross-border trade, but no revenues for A or B. In a world in which international trade and investment are important, but taxes (unlike tariffs) cannot be reduced to zero, the single tax principle is the best option.

\subsection{Dividing the tax base: the benefits principle}

Having defined one goal of the international tax regime as taxing cross-border income once, the next question is how to divide that base among the various jurisdictions laying claim to it. The benefits principle states that the residence jurisdiction has the primary right to tax passive (investment) income, while the source jurisdiction has the primary right to tax active (business) income. As explained above, this division also determines the appropriate rate of tax for purposes of the single tax principle.

This distinction, which stems from the work of the League of Nations in the 1920s, can also be justified on both theoretical and pragmatic grounds. On a theoretical level, the benefits principle makes sense because it is primarily individuals who derive investment income, whereas it is primarily corporations that derive business income. For individuals, residence-based taxation makes sense. First, residence is relatively easy to determine in the case of individuals. Second, because most individuals are part of only one society, distributive concerns can be addressed most effectively in the country of residence. Third, residence overlaps with political allegiance and, in democratic countries, residence-based taxation is a proxy for taxation with representation.

In the case of multinational corporations, source-based taxation seems generally preferable. First, the grounds for taxing individuals on a residence basis do not apply to corporations. The residence of corporations is diffi-

12. See e.g. Avi-Yonah, Reuven S., "Why Tax the Rich? Efficiency, Equity, and Progressive Taxation (Review of Slemrod, Does Atlas Shrug? The Economic Consequences of Taxing the Rich)", 111 Yale Law Journal 1391 (2002); and Avi-Yonah, Reuven S., "Corporations, Society and the State: A Defense of the Corporate Tax”, 90 Virginia Law Review 1193 (2004).

13. Graetz, Michael J. and Michael M. O'Hear, "The 'Original Intent' of U.S International Taxation”, 46 Duke Law Journal 1021 (1997). 
cult to establish and relatively meaningless. Residence based on the place of incorporation is formalistic and subject to the taxpayer's control, while residence based on management and control can also be manipulated. Moreover, multinationals are not part of a single society, and their income does not belong to any particular society for distributive purposes. Finally, multinationals can exert significant political influence in jurisdictions other than the residence jurisdiction of their parent company; therefore, the concern about taxing foreigners who lack the ability to vote is less applicable to multinationals.

Second, source-based taxation is consistent with a benefits perspective on justifying tax jurisdiction. Source jurisdictions provide significant benefits to corporations that carry on business activities within them. Such benefits include the provision of infrastructure or education, as well as more specific government policies such as keeping the exchange rate stable or interest rates low. These benefits justify source-based corporate taxation in the sense that the host country's government bears some of the costs of providing the benefits that are necessary for earning the income. As T.S. Adams wrote in 1917: "A large part of the cost of government is traceable to the necessity of maintaining a suitable business environment." These costs justify imposing a tax as compensation to the government bearing them.

On a more pragmatic level, as Adams also observed, since the source jurisdiction has by definition the "first bite at the apple", that is, it has the first opportunity to collect the tax on payments derived from within its borders, it would be extremely difficult to prevent source jurisdictions from imposing the tax. "Every state insists upon taxing the non-resident alien who derives income from source [sic] within that country, and rightly so, at least inevitably so." Thus, as Michael Graetz and Michael O'Hear observed, even if economists tend to prefer pure residence-based taxation, this recommendation is unlikely to be followed in practice. ${ }^{14}$ This is particularly the case for business income derived from large markets, where there is little fear that the foreign investor will abandon the market because of source-based taxation. For portfolio investment, however, even large source countries like the United States have tended to abandon source-based taxation for fear of driving away mobile capital. Thus, business income is a better candidate for source-based taxation than investment income.

The division between active (mostly corporate) and passive (mostly individual) income also makes sense because it is congruent with the single tax principle since most of the rate divergence among taxing jurisdictions arises in the individual income tax, while corporate tax rates have tended to converge. The top marginal personal income tax rate among the OECD Member countries varied in 2006 from 7.5\% (Switzerland) to 53.8\% (Germany). This variability is acceptable for purposes of the single tax principle because, under the benefits principle, most income derived by individuals in cross-border transactions is investment income that generally is subject only to residence-country tax. Therefore, the res- idence-country rate typically determines the single tax rate for investment income.

Corporate tax rates, on the other hand, do not vary so widely (and also tend to be flat rather than progressive). Among the OECD Member countries, the corporate tax rate in 2006 ranged from $8.5 \%$ (Switzerland) to 35\% (United States), but 22 out of the 30 OECD members had rates in the $25 \%$ to $35 \%$ range. Thus, for purposes of the single tax principle, the rate applied is generally the residence rate for individual (mostly investment) income and a rate in the $25 \%$ to $35 \%$ range for corporate (mostly business) income. It is congruent with both the single tax and benefits principles, however, to have residual taxation by residence or source jurisdictions in cases where the jurisdiction that has the primary right to tax under the benefits principle refrains from doing so. Thus, according to the single tax and benefits principles, all income from cross-border transactions under the current rate structures should be taxed at a rate between approximately $25 \%$ (the lower end of the source rates) and approximately $55 \%$ (the higher end of the residence rates).

Neither the single tax principle nor the benefits principle provides a clear answer to the question of how to divide the corporate income tax base among the various jurisdictions providing benefits. Market prices can provide an answer when transactions are at arm's length, but not when they are between related parties (and there are no comparable arm's length transactions). In addition, the single tax principle requires that tax be imposed even on income derived from a jurisdiction that chooses not to levy a tax in return for the benefits it provides. These issues are addressed further below.

It is useful to summarize the resulting structure of international taxation in Table 1, which divides the world into two categories of taxpayers, resident and non-resident. For each category, there is a further division between active (business) and passive (investment) income. Active income is taxed primarily at source, while passive income is taxed primarily at residence.

Table 1: Structure of the international tax regime

\begin{tabular}{|llll|}
\hline \multicolumn{4}{|c|}{ WORLD } \\
\hline \multicolumn{2}{|c|}{ Residents } & \multicolumn{2}{c|}{ Non-residents } \\
\hline active & passive & active & passive \\
income & income & income & income \\
low tax & high tax & high tax & low tax \\
\hline
\end{tabular}

\section{Current Challenges to the International Tax Regime}

Parts 2 to 4 laid out the thesis that an international tax regime exists and that it has a coherent structure based on two principles, the single tax principle and the bene-

14. Id. 
fits principle. While the benefits principle is broadly accepted as reflecting the consensus compromise reached under the auspices of the League of Nations in the $1920 \mathrm{~s},{ }^{15}$ there is a debate on whether an international tax regime exists ${ }^{16}$ and, in particular, whether it incorporates the single tax principle. ${ }^{17}$ Whether preventing double non-taxation is an appropriate goal of international tax has been hotly debated, e.g. at the 2004 Vienna Congress of the International Fiscal Association.

In this concluding part, I survey three relatively recent developments that undermine the single tax principle: tax competition for passive income, tax competition for active income, and tax arbitrage. I then discuss various reactions to these developments at both the national and supranational levels (primarily through the OECD) and assess their success in curbing the threat to the single tax principle. Finally, I discuss the implications of these reactions for the debate surrounding the existence of the international tax regime. In my opinion, these reactions prove that an increasing number of important tax administrations as well as the OECD believe in the single tax principle and seek to implement it in practice.

\subsection{Tax competition for passive investment}

Since the United States unilaterally abolished withholding on portfolio interest in 1984, there has been a distinct trend not to tax interest at source, which has spread to other forms of passive income such as capital gains, royalties, rents, and even dividends. I have explained elsewhere ${ }^{18}$ why a combination of officially sanctioned loopholes (such as the portfolio interest exemption), source rules (such as the rules for capital gains and for payments under derivative financial instruments), and treaty reductions have led the United States not to apply its withholding tax to almost all forms of passive investment income that economically derives from the US market.

The lack of a withholding tax combined with the existence of tax havens makes it almost impossible for residence countries to effectively tax passive income. In the absence of a withholding tax, source countries have no interest in collecting information on payments of passive income to non-residents. Tax havens have bank secrecy laws, and payments can be made to them from a source country without any information being collected that can be exchanged with the residence country under the exchange of information article of the applicable treaty (Art. 26 of the OECD Model).

The result is widespread double non-taxation of investment income: no withholding at source and no effective residence taxation because of no effective exchange of information. It is hard to estimate how much tax is evaded in this way, but Vito Tanzi has estimated that as much as USD 7 trillion in interest income escape taxation. ${ }^{19}$ For the US, the annual revenue loss due to this type of evasion has been estimated to be USD 50 billion. ${ }^{20}$
Since 1998, however, residence countries have taken a series of steps to combat this phenomenon. This is reflected in the steps taken by the OECD and the EU and by national tax administrations. The OECD addressed the problem of tax havens in its 1998 report on harmful tax competition and has exerted significant pressure on tax havens to allow effective exchange of information. It has also adopted a new, much stronger version of Art. 26 of the OECD Model and has drafted a multilateral exchange of information treaty. The EU has adopted the Savings Directive, which requires the Member States to cooperate in ensuring that payments of interest and other forms of passive income from one Member State to another are subject to either withholding or information reporting. And national tax administrations have concluded exchange of information agreements with an expanding number of tax havens. The US has such agreements, for example, with most of the Caribbean jurisdictions listed as tax havens by the OECD. The US is also cooperating in exchanging information with the EU by forcing financial institutions to collect information on payments to the EU that are covered by the portfolio interest exemption. Even Switzerland has agreed to cooperate and relax its strict bank secrecy laws.

I have expressed some doubts about whether these initiatives are working. In particular, the actual agreements reached with tax havens tend to fall short of the expanded version of Art. 26 envisaged by the OECD. We still lack universal tax ID numbers to help tax administrations use the information that they get. And even one non-cooperating tax haven can defeat the whole effort if payments can be routed through it. This is why I still believe that a better solution is a coordinated withholding tax imposed by the OECD countries (the US, the EU Member States and Japan) which is refundable upon a showing that the income has been declared to the residence country. After all, nobody can afford to leave his funds in tax havens; they must be invested in the OECD countries to earn a decent rate of return.

The key point here, however, is not whether the effort is succeeding, but that it is made. In my opinion, it is clear that, in the view of all 30 OECD countries (as well as all the EU Member States, which largely overlap with the OECD), the single tax principle is valid, and double nontaxation of passive income is not acceptable. Otherwise, they would not have reacted to the collapse of sourcebased taxation of such income after 1984 by trying so

15. See Ault, Hugh J., "Corporate Integration, Tax Treaties and the Division of the International Tax Base: Principles and Practices”, 47 Tax Law Review 565 (1992); and Graetz and O'Hear, supra note 13.

16. See Rosenbloom, "International Tax Arbitrage and the 'International Tax System", and Rosenbloom, "Cross-Border Arbitrage: The Good, The Bad and The Ugly", both supra note 1 .

17. See Rosenbloom, "Cross-Border Arbitrage: The Good, The Bad and The Ugly", supra note 1.

18. See Avi-Yonah (1996), supra note 3 .

19. Tanzi, Vito, Taxation in an Integrating World (1995).

20. Guttentag, Joseph and Reuven S. Avi-Yonah, "Closing the International Tax Gap", in Sawicky, Max B. (ed.), Bridging the Tax Gap: Addressing the Crisis in Federal Tax Administration (2005). 
hard to tax it on a residence basis (where, in accordance with the benefits principle, it should be taxed).

\subsection{Tax competition for active investment}

As I have explained at length elsewhere, ${ }^{21}$ tax competition for foreign direct investment (FDI) has been growing steadily since about 1980 and now means that multinationals can hope to escape any tax on their cross-border income. Suppose a multinational enterprise (MNE) is resident in country $\mathrm{A}$, has its production facilities in country B, and sells its products in country C. Country C can only tax the MNE if it has a permanent establishment therein and, in the age of electronic commerce, that may be possible to avoid. Country B typically does not tax the MNE because it is a "production tax haven," i.e. a country that refrains from taxing production activities by MNEs while imposing a general corporate tax on domestic corporations. Country A also typically would not tax the resident MNE on a current basis because it is afraid of MNE headquarters migrating to other countries (either by inversion-type transactions or by a takeover by foreign MNEs) and of new MNEs being incorporated elsewhere. As a result, an MNE like Intel ends up paying no tax at all on its foreign-source income (and, if it can deduct stock options, also on its US-source income).

The economic data show that this type of tax competition exists, although it tends to affect more the corporate tax revenues in developing countries (country B in the example) than in developed countries (countries A and C). ${ }^{22}$ The reason is that the OECD countries have been reducing the permanent establishment threshold ${ }^{23}$ and that it turns out that, for most MNEs, it is difficult to avoid having a permanent establishment even in the age of e-commerce. ${ }^{24}$

In this case, however, the OECD has also been working hard to combat the tax competition phenomenon by putting pressure on both OECD members and nonmembers to abolish production tax havens as well as to abandon tax sparing rules in treaties that foster double non-taxation. In addition, the WTO has been pressuring developing countries to abandon production tax havens that amount to export subsidies, and many Latin American countries have in fact abandoned their production tax haven regimes in the Doha Round. Finally, countries have been taking steps to defend the residence-based taxation of their MNEs by adopting or strengthening their CFC rules (26 countries now have such rules, which were pioneered by the US in 1962) and combating inversion transactions (e.g. IRC Sec. 7874).

Again, the main point is not whether these efforts have been successful, although at least for the OECD members they seem to have stopped the erosion of the corporate tax base that was evident in the 1990s. The main point is that, by adopting such measures, the OECD members (as well as the WTO) show that they do not accept the double non-taxation of active income and are trying to protect the taxation of such income at source (with residual taxation by the residence country if there is no taxation at source). I believe this trend will continue until effective residence-based taxation by the OECD members stops developing countries from engaging in harmful tax competition.

\subsection{Tax arbitrage}

Tax arbitrage can be defined as transactions that are designed to take advantage of differences between national tax systems to achieve double non-taxation. Thus, tax arbitrage directly negates the single tax principle.

There is no question that Rosenbloom is correct in his assertion that countries did not always care about tax arbitrage. The first US tax treaty was with France in 1937, when France was purely territorial, so the US reduced its tax at source in the knowledge that the income would not be taxed at residence.

But I believe that developments since 1984 show that the US as well as the other OECD Member countries have reached a consensus that rejects tax arbitrage. In 1984, the US terminated its treaty with the Netherlands Antilles on the ground that the US should not have treaties with countries that do not tax on a residence basis. Since then, it has been clear that the US will not enter into treaties with tax havens and that the US views reductions in source-based taxation as premised upon the income being taxed by the residence state. This is why, since 1986, the US has insisted on limitation on benefits rules in all its tax treaties, which are designed to prevent reductions in source-based taxation benefiting non-treaty country residents precisely because such non-treaty residents may not be taxable on a residence basis. Domestically, these rules have been bolstered by court cases and by regulations against the use of conduits to achieve treaty benefits. It has also been adopted by the OECD through changes to the Commentary on Art. 1 of the OECD Model.

The negative attitude of the US to tax arbitrage and double non-taxation is also evident outside the treaty context. Also in 1984, the US adopted the dual consolidated loss rule, which is designed to prevent a taxpayer from using one economic loss in two taxing jurisdictions. As Rosenbloom admitted, ${ }^{25}$ this rule (which was recently expanded in the US regulations) makes no sense unless the US believes that double non-taxation is bad. In the 1990 s, the US took a series of steps to combat specific tax arbitrage transactions based on "check the box", such as

21. Avi-Yonah, "Globalization, Tax Competition, and the Fiscal Crisis of the Welfare State", supra note 3.

22. Keen, Michael and Alejandro Simone, "Is Tax Competition Harming Developing Countries More Than Developed", 34 Tax Notes International 1317 (2004)

23. Le Gall, Jean-Pierre, "Can a Subsidiary be the Permanent Establishment of Its Foreign Parent", 2006 Tillinghast Lecture, New York University Law School (forthcoming in Tax Law Review, 2007).

24. Avi-Yonah, supra note 11; Avi-Yonah, Reuven S., "Tax Competition and E-Commerce", 23 Tax Notes International 1395 (2001).

25. Rosenbloom, "International Tax Arbitrage and the 'International Tax System”, supra note 1. 
IRC Sec. 894(c) (the reverse hybrid rule) and Notices 98 5 and 98-11. While the specific notices were later withdrawn, the Bush administration continues to fight tax arbitrage, as evidenced by recent regulations on tax arbitrage transactions involving the foreign tax credit. ${ }^{26}$

The same negative view toward tax arbitrage can be seen in other countries. A 2006 article in the International Tax Review lists the new anti-tax arbitrage rules that were recently adopted in Australia, Canada, Japan and the UK; and even Ireland (with a corporate tax rate of only $12.5 \%$ ) adopted such rules in 2006 . The UK rules are particularly comprehensive and have drawn bitter complaints from tax practitioners, to no avail.

In 2006, Rosenbloom wrote that, although an international tax regime may exist and although tax treaties can be regarded as a "closed" system which conditions reductions in source taxation on taxation by the residence country, the single tax principle is still a mirage: "At the level of specific rules, however, there is no mechanism for enforcing, or even attempting to enforce, either the benefits principle or the single tax principle .... At the level of individual transactions, in fact, it is hard to discern the existence of any international tax regime at all."27

Rosenbloom may be right about that - as a practitioner specializing in tax arbitrage transactions, he should know. But at the policy level, I disagree with his view that "an effort to foreclose cross-border arbitrage opportunities is not and should not be a first-rank policy objective of the United States". We can argue about the "should not", and that is the point of our earlier debate on this topic. ${ }^{28}$
But in face of the accumulating evidence to the contrary, it seems to me hard to argue about the "is not": the US as well as the other OECD Member countries are in fact concerned about tax arbitrage and, by extension, about double non-taxation, both in the treaty context and outside it.

\section{Conclusion}

This article has attempted to describe the contours of the international tax regime. I have tried to show that such a regime exists and that it is based on the single tax and benefits principles. Moreover, I believe the regime, both through treaties and through actual practice, can be regarded as part of customary international law. Whether or not the last conclusion is valid, it is hard to argue with the proposition that all countries, even the United States, face significant practical difficulties in attempting to depart from the international tax regime.

If the above is true, I believe that we can do better. In particular, it would help if countries explicitly articulated that they are trying to adhere to the single tax and benefits principle and take those principles into account in drafting their tax laws. Moreover, the OECD should take these principles more explicitly into consideration in revising the OECD Model and revise it so that it functions better to prevent both double taxation and double non-taxation. But that is a topic for another day. ${ }^{29}$
26. Reich, Yaron Z., "International Arbitrage Transactions Involving Creditable Taxes" (forthcoming in Taxes (University of Chicago publication), 2006); Peaslee, James M., Creditable Taxes as an Expense in Applying the Economic Profit Test - Here We Go Again? (2006).

27. Rosenbloom, "Cross-Border Arbitrage: The Good, The Bad and The Ugly", supra note 1 .

28. Rosenbloom, "International Tax Arbitrage and the 'International Tax System", supra note 1; Avi-Yonah, "Globalization, Tax Competition, and the Fiscal Crisis of the Welfare State", supra note 3.

29. Avi-Yonah, Reuven S., Wolfgang Schön and Richard Vann, The Treatment of Business Profits under Tax Treaties (forthcoming). 